\title{
The Influence of P Content on the Electrocatalytic Properties of Pd-P Electroless Alloys for HER on Aqueous/Ethanolic Media
}

\author{
Eveline de Robertis ${ }^{a, b}$, Alda M. Fundo ${ }^{a}$, Artur J. Motheo ${ }^{b}$ and Luísa M. Abrantes ${ }^{*, a}$ \\ ${ }^{a}$ Departamento de Química e Bioquímica, F.C.U.L., Edifício C8, Campo Grande 1749-016 Lisboa, Portugal \\ ${ }^{b}$ Instituto de Química de São Carlos, Universidade de São Paulo, Av. Trabalhador São Carlense 400, CP 780, \\ 13566-970 São Carlos - SP, Brazil
}

\begin{abstract}
Prepararam-se filmes de Pd-P sobre aço carbono, por deposição electroless, usando hipofosfito de sódio como agente redutor. As ligas foram caracterizadas (estrutura e morfologia) por Difração de Raios X (DRX) e Microscopia Eletrônica de Varredura (MEV) o que revelou que o grau de amorficidade aumenta com a quantidade de $\mathrm{P}$ co-depositado. A resposta de eletrodos de Pd-P, com diferentes composições, para a reação de evolução de hidrogênio (REH), analisada em soluções de água-etanol e de etanol puro, mostraram que o caráter amorfo das ligas aumenta a aptidão para adsorver hidrogênio. Os resultados sugerem que filmes de Pd-P com adequados teores em fósforo (17\% at.) são superfícies de eletrodo apropriadas para a hidrogenação de substratos orgânicos.
\end{abstract}

Pd-P modified carbon steel electrodes have been prepared by electroless deposition using sodium hypoposphite as reducing agent. The alloy characteristics (structure and morphology) were analysed by X-Ray Diffraction (XRD) and Scanning Electronic Microscopy (SEM) revealing that the degree of amorphicity increases with the amount of co-deposited P. The behaviour of Pd-P with different compositions towards the HER, analysed in water-ethanol and pure ethanol solutions, have shown that the alloy amorphous character enhances the hydrogen adsorption. The results suggest that Pd-P films with adequate phosphorous content (17\% at.) are suitable electrode surfaces for organic substrates hydrogenation.

Keywords: electroless deposition, Pd-P alloys, electrocatalytic activity

\section{Introduction}

The preparation of modified electrodes with catalytical properties for the hydrogen evolution reaction (HER) has been subject of intensive research, ${ }^{1,2}$ due to its relevant use in industrial applications. The principal aim is to find a low cost and efficient cathodic material for the preparation of electrodes with high surface area. In this context, the metallic electroless deposition is considered an interesting alternative. ${ }^{3,4}$

Besides the common utilisation of $\mathrm{Ni}$ and $\mathrm{Pt}$ for HER, Pd presents very good catalytic properties and it has also been used for hydrogenation reactions, ${ }^{5,6}$ mainly as dispersed particles in low cost substrates. ${ }^{7-9}$ For this purpose, Pd electroless baths have been improved and the respective deposits investigated ${ }^{10-13}$ reports on its use to prepare membranes ${ }^{14,15}$ and in electronic components ${ }^{16,17}$ reveal the increasing interest on electroless $\mathrm{Pd}$.

* e-mail: luisa.abrantes@fc.ul.pt
The behaviour towards HER of Ni based alloys, namely Ni-P is still a controversial since the alloy $\mathrm{P}$ content seems to be critical for the catalytic activity of the electrode. Paseka ${ }^{18,19}$ endorses that some of these materials are electroactive for the hydrogen evolution reaction, while others, especially electrodes with high phosphorus content, ( $>12.5 \%$ at.) are inactive. Buchardt et al..$^{20,21}$ attribute the good performance of these electrodes to the amorphous structure. Other authors ${ }^{22,23}$ support that films electrocatalytic activity does not depend solely on the phosphorus content, but would also be related to the preparation method as well as to any treatments that the films would be subject to.

In this work, electroless Pd-P deposited on 1020 mild steel substrate is investigated, in order to relate the presence and amount of the non-metallic element to their amorphous character and to electrocatalytic activity, namely within the potential domain suitable for HER. Since the effective hydrogenation of organic molecules, obviously a much milder process than the established one occurring at high 
temperatures and pressures, ${ }^{24,25}$ requires the use of organic or mixed media, the produced Pd-P alloys are tested and their electrochemical behaviour analysed, using solutions of tetrabutylammonium perchlorate (TBAP) in ethanol and $50 \%(\mathrm{v} / \mathrm{v})$ ethanol/water.

\section{Experimental}

AISI 1020 carbon steel plates of 10x10x1 mm were used as substrate for deposition of the Pd-P electroless films. The substrate plates were coarsely polished using emery paper (1000) and successively finer grades of alumina (down to $0.05 \mu \mathrm{m}$ ) until mirror finishing was generated, after which an electrolytic degreasing ${ }^{26}$ was performed.

A stable plating bath ${ }^{12}$ of a palladium-ammine complex, $\mathrm{Pd}\left(\mathrm{NH}_{3}\right)_{4} \mathrm{Cl}_{2}$, was prepared by addition of $\mathrm{PdCl}_{2}(0.010 \mathrm{~mol}$ $\left.\mathrm{dm}^{-3}\right)$ to ammonia solution $\left(2.35 \mathrm{~mol} \mathrm{dm} \mathrm{NH}_{4} \mathrm{OH}\right)$ and heating until the initially formed precipitate is dissolved. The solution was stirred for $30 \mathrm{~min}$. Different solutions were prepared with $0.10 ; 0,20 ; 0.30$ and $0.40 \mathrm{~mol} \mathrm{dm}^{-3}$ of $\mathrm{NaH}_{2} \mathrm{PO}_{2}$ and $0.50 \mathrm{~mol} \mathrm{dm}^{-3}$ of ammonium chloride $\left(\mathrm{NH}_{4} \mathrm{Cl}\right)$ added. All the solutions were made from P.A. grade chemicals and Millipore water. A double wall cell was used, keeping the temperature at $50.0 \pm 0.1{ }^{\circ} \mathrm{C}$ by water circulation. The electroless deposition time was $140 \mathrm{~min}$.

The Pd-P films structure was analysed by X-ray diffraction, using a Philips PW 1710 diffractometer with monochromatic $\mathrm{Cu}-\mathrm{K} \alpha$ radiation $(\lambda=1.54056 \AA)$; the diffractograms were recorded using step scan (step size $0.030^{\circ}, 10 \mathrm{~s}$ count time per step) at $20-140^{\circ}$ range.

Surface morphology was examined using a Hitachi S-2400 Scanning Electron Microscope (SEM). The average alloy composition was determined from semi-quantitative Energy Dispersive X-ray Spectrometry (EDS - Rontec Edwin with $20 \mathrm{keV}$ beam energy) attached to the SEM.

The polarisation curves were obtained in a conventional three compartment cell with Pt as secondary and SCE as reference electrodes, at room temperature, using a Potentiostat Wenking ST 72 coupled to a Scan Generator Wenking model VSG 72 . The data requiring 1-4 min polarization at each potential value were collected in an Omnigraphic-Houston Instrument $2000 \mathrm{X}$-Y-t recorder. Commercial Pd disc $(\phi=5 \mathrm{~mm})$ and Pd-P electroless films were tested towards hydrogen evolution reaction (HER) in $\mathrm{NaOH} 1 \mathrm{~mol} \mathrm{dm}^{-3}$ and in two different solutions with TBAP $0.1 \mathrm{~mol} \mathrm{dm}^{-3}$ and (i) $\mathrm{H}_{2} \mathrm{O} / \mathrm{EtOH} 50 \%$ (v/v), (ii) EtOH. Absolute ethanol $\left(0.2 \% \mathrm{H}_{2} \mathrm{O}\right)$ Panreac of analytical grade was used.

\section{Results and Discussion}

The selected range of concentrations for the reducing agent is a result of a preliminary study which showed that the good adherence of the resulting electroless films on the pre-cleaned and polished carbon steel substrates requires sodium hypophosphite concentrations higher than $0.10 \mathrm{~mol} \mathrm{dm}^{-3}$.

Figure 1 shows the diffraction spectra obtained for Pd-P films on 1020 steel, prepared with different concentrations of $\mathrm{NaH}_{2} \mathrm{PO}_{2}$ in solution. The $\mathrm{Pd}$ characteristic reflections are observable but with a noticeable widening of the main Pd diffraction band and a loss of definition of the Pd plane peak (220) as the reducing agent concentration is increases. The degree of amorphicity of the film owing to the inclusion of $\mathrm{P}$ in the deposit leads to a considerable broadness at the $\mathrm{Pd}$ (111) diffraction line in the angle range $2 \theta=32-48^{\circ}$; on the other hand, no conclusions about the possible occurrence of other palladium phosphides phases $\left(\mathrm{Pd}_{7} \mathrm{P}_{3}\right.$ and $\left.\mathrm{Pd}_{15} \mathrm{P}_{2}\right)$ can be taken since their principal reflections are also within that angular domain (Figure 1d). Notwithstanding, the influence of the phosphorous content have been further analysed by considering the Sherrer approximation, ${ }^{27,28}$

$$
D \approx \frac{0.9 \lambda}{\beta \cos \theta}
$$

where $\beta$ is the half-width of the diffraction line, in radians, $\theta$ the Bragg angle and $\lambda$ the $\mathrm{Cu}-\mathrm{k}_{\alpha}$ radiation (1.54056 $\AA$ ).

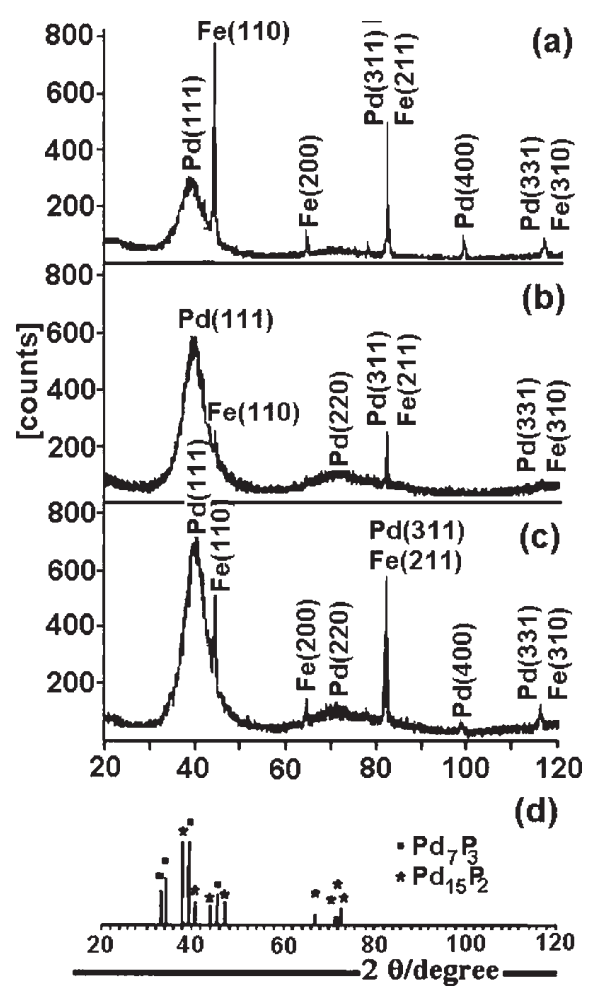

Figure 1. Diffractograms of Pd-P films over mild steel 1020, deposited by electroless with (a) $16.7 \%$ at. P, (b) $15.7 \%$ at. P, (c) $13.9 \%$ at. $\mathrm{P}$ and (d) main XRD patterns of $\mathrm{Pd}_{7} \mathrm{P}_{3}$ and $\mathrm{Pd}_{15} \mathrm{P}_{3}$ alloys. 
The so estimated average crystallite dimensions, in films prepared under different conditions are given in Table 1. It can be seen that the increase of foreign atoms in the metallic matrix decreases the size of microcrystallites.

Table 1. Phosphorous content and crystallite dimensions in Pd-P electroless films prepared from solutions with different reducing agent concentrations

\begin{tabular}{ccc}
\hline $\begin{array}{c}{\left[\mathrm{H}_{2} \mathrm{PO}_{2}^{-}\right] /} \\
\left(\mathrm{mol} \mathrm{dm}^{-3}\right)\end{array}$ & $\begin{array}{c}\text { P content / } \\
\% \text { at. }\end{array}$ & $\begin{array}{c}\text { Crystallite dimensions / } \\
\mathrm{nm}( \pm 0.1 \mathrm{~nm})\end{array}$ \\
\hline 0.20 & 13.9 & 25.9 \\
0.30 & 15.7 & 23.3 \\
0.40 & 16.7 & 22.4 \\
\hline
\end{tabular}

As revealed by SEM (Figure 2), the electroless Pd-P deposits show globular protuberances resulting in a quite irregular surface. The observed deposit evolution, through $3 \mathrm{D}$ growth of laterally coalescent hemispherical nuclei is similar to that reported for Ni-P. ${ }^{29,30}$ The growth of those nodules follows the background substrate morphology, promoting the formation of inhomogeneous clusters.

The influence of the electrolyte composition on the rate of electroless deposition and thus on the size and

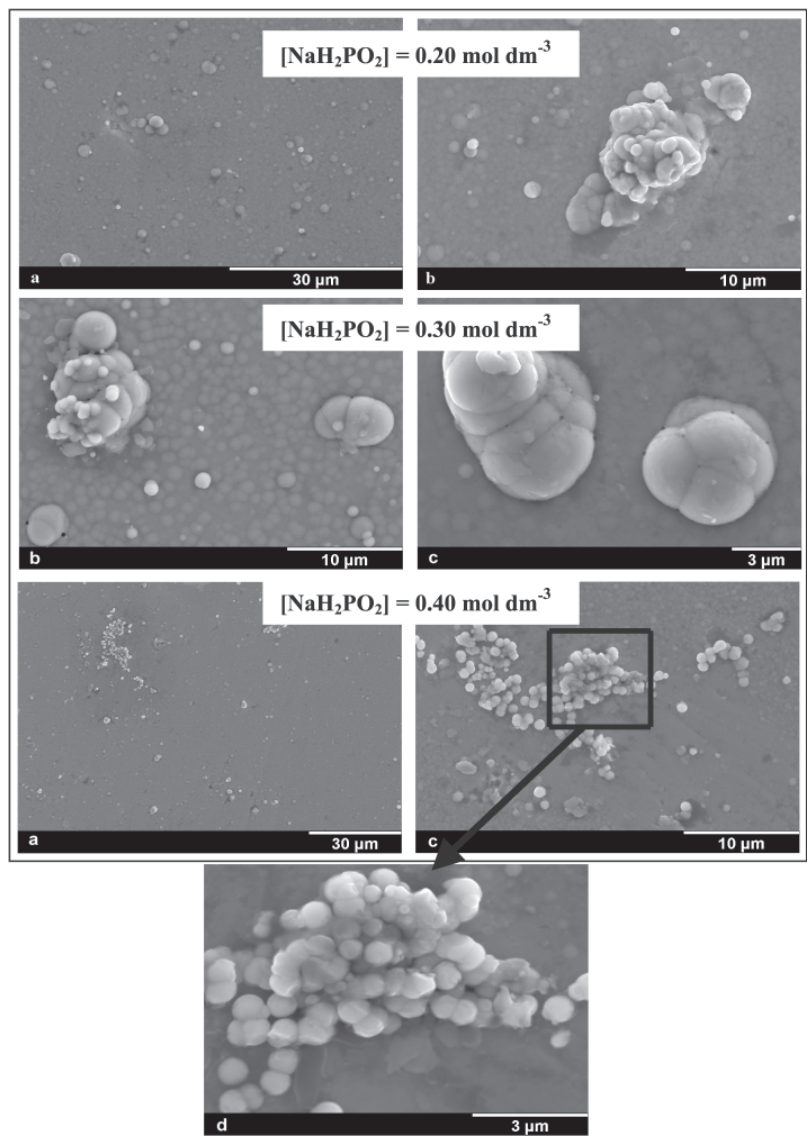

Figure 2. Scanning electron microscopy of Pd-P electroless with different $\mathrm{P}$ content. distribution of Pd-P particles may also be retrieved from the SEM images: a larger amount of agglomerates formed by smaller sized particles are found in the alloys with higher phosphorus content and therefore prepared from the reducing agent most concentrated solution.

The ultimate goal of this preliminary study is to evaluate the performance of the so-obtained Pd-P alloys as cathodes for the electrohydrogenation of organic molecules.

The use of amorphous materials in electrocatalysis has been subject of many reported studies; special attention has been paid to Ni-based alloys ${ }^{20,21,24,25}$ being scarce the literature in what concerns Pd-electroless as electrode material for organic substrates hydrogenation.

Changing the $\mathrm{P}$ content, Pd-P electroless alloys display different crystalline/amorphous character and thus the investigation of their electrocatalytic activity in a potential domain suitable for HER, shall indicate the best conditions for the observation of the required adsorption of atomic hydrogen.

Figure 3 contrasts the responses obtained for pure $\mathrm{Pd}$ and Pd-P alloy (13.9\%) in $\mathrm{NaOH} 1 \mathrm{~mol} \mathrm{dm}^{-3}$ solution. The remarkable difference in the current recorded in the overpotential range from about $-0.6 \mathrm{~V}$ to $-0.9 \mathrm{~V}$ indicates that the hydrogen is adsorbed at the alloy surface for a relatively larger period of time than at pure Pd. However the hydrogen absorption and the very likely formation of metallic hydride ${ }^{31,32}$ must also be taken into account in the HER at palladium. That process competes with the adsorption and subsequent gas evolution and may influence the kinetics of HER. In pure Pd the atomic recombination and subsequent $\mathrm{H}_{2}$ evolution appears to occur faster, probably due to a major absorption of hydrogen in Pd-P alloy.

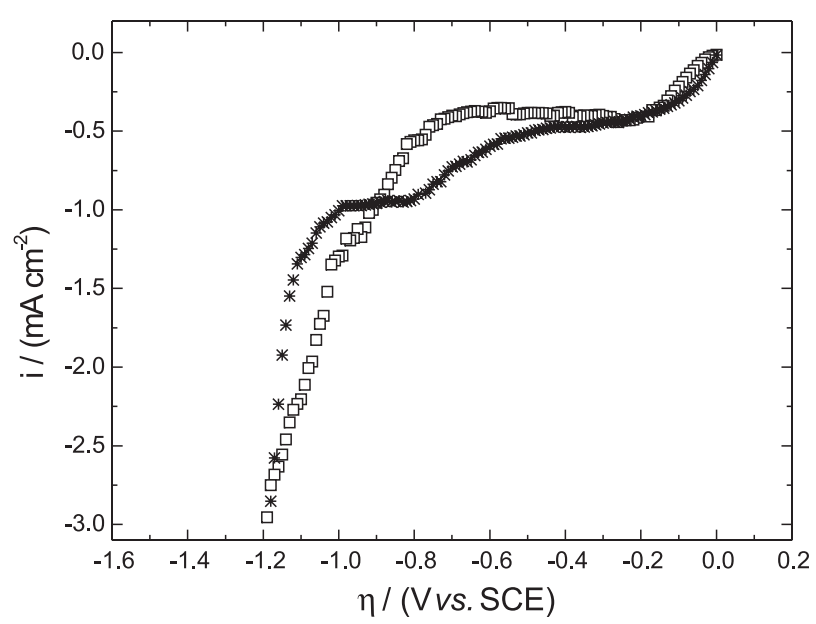

Figure 3. Steady state polarisation curves of $\mathrm{Pd}(\square)$ and Pd-P $\left(13.9\right.$ at $\%$ P) $(*)$ in $\mathrm{NaOH} 1 \mathrm{~mol} \mathrm{dm}^{-3}$. 
Since mixed media, namely aqueous - alcoholic solutions, facilitate the solubility of the envisaged organic substrates, the catalytic activity of both commercial $\mathrm{Pd}$ and Pd-P electroless samples towards HER from 50\%/50\% (v/v) $\mathrm{H}_{2} \mathrm{O} / \mathrm{EtOH}$ and also from pure ethanol solutions has been analysed, as shown in figure 4. Care has been taken in using fresh solution for each essay and in keeping similar the experimental conditions in the whole set of experiments. In spite of the known changes in the solution $\mathrm{pH}$ in non-buffered media, the obtained steady state polarisation curves (where the current density refers to the geometrical area of the working electrodes) allow preliminary information. In the mixed media (Figure 4 a) the systems present a pretty close behaviour from about 0 to $-0.7 \mathrm{~V}$; for lower potential values the effect of increasing the $\mathrm{P}$ content in the electroless alloy on its electrocatalytic response is clearly observed. This beneficial influence is more noticeable in the responses obtained in pure ethanol (Figure 4b).

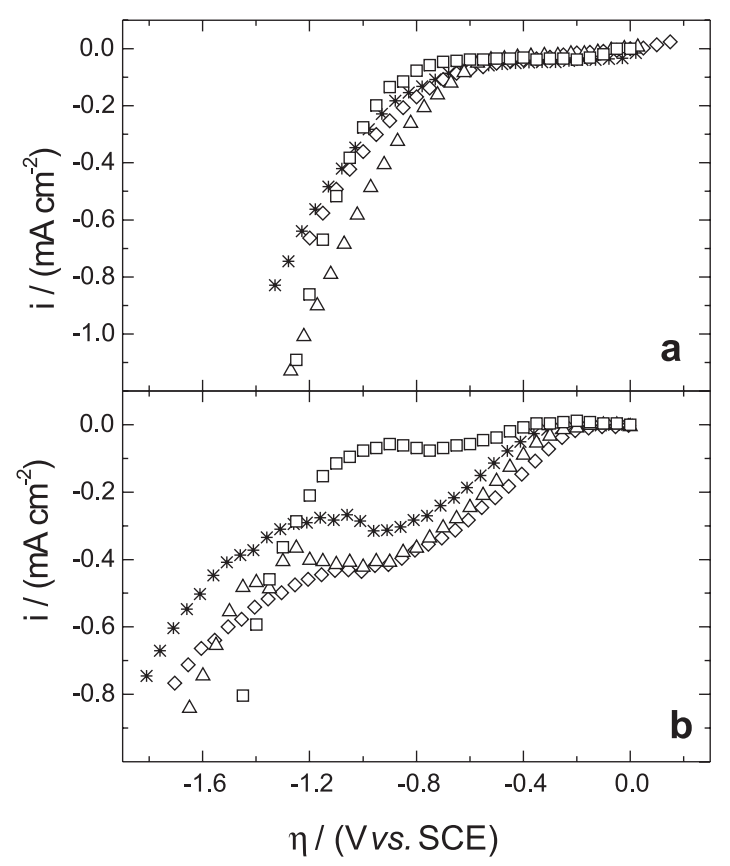

Figure 4. Steady state polarisation curves in (a) 50/50 \% vol. $\mathrm{H}_{2} \mathrm{O}-$ $\mathrm{EtOH}$ and (b) $100 \% \mathrm{EtOH}$ at $(\square)$ pure Pd disk and Pd-P alloy electrodes with $(*) 13.9$ at $\% \mathrm{P}(\diamond) 15.7$ at. $\% \mathrm{P}$ and $(\triangle) 16.7$ at. \% P.

It is known that the HER rate is determined by the energy of adsorption and desorption of hydrogen; a low adsorption energy is associated to an incomplete surface coverage and thus to a low reaction rate, whereas when the adsorption energy is too high the overall reaction rate decreases due to the reduced ability of the species to desorption.

As reported by Burchardt et al. ${ }^{20,21}$ for Ni-P alloys, the observed behaviour for Pd-P supports that the amorphous phase increase the amount and residence time of adsorbed hydrogen, and therefore Pd-P alloys appears as promising materials for the electrocatalytic hydrogenations.

The obtained results also show the importance of the degree of amorphicity, (or in other words of the P content), pointing to $\mathrm{Pd}-\mathrm{P}$ film with about $17 \%$ at. $\mathrm{P}$ as a suitable electrode to perform the HER, in alcoholic medium.

The effect of subjecting the electrode to the above mentioned potential domain in the current response reproducibility has been checked performing steady state polarisation curves in direct and reverse sense, in ethanol, using different potential windows. Film thickness up to $20 \mu \mathrm{m}$ has been tested. Although the respective current curves recorded within a potential domain where the hydrogen adsorption prevails present hysteresis, when the cathodic limit is extended to the region of hydrogen evolution, the similarity of both polarisation and depolarisation responses show that the electrode recovers the initial activity. The absence of no significant structural modifications promoted by the electrode polarisation has also been confirmed by XRD analysis.

\section{Conclusions}

The $\mathrm{P}$ content in electroless $\mathrm{Pd}$ films increases with the concentration of the reducing agent. Pd-P alloys characterization by XRD enabled to differentiate structural changes induced by the presence of the non-metallic element, namely an increase in the degree of amorphicity with the amount of co-deposited phosphorus; films morphology also depends on the alloy composition, being the particle size and distribution (observed by SEM) more irregular as the concentration of $\left(\mathrm{H}_{2} \mathrm{PO}_{2}^{-}\right)$in the preparation solution.

The presence of $\mathrm{P}$ has proven to be an important factor for the electrode ability to adsorb hydrogen. The amorphous character of Pd-P (thus its composition and morphology) is responsible for the observed good electrocatalytic activity towards hydrogenation reactions. In water free electrolyte, the performance of alloys with relatively high amount of $\mathrm{P}$ (17\% at.) when compared with the pure metal behaviour opens up promising possibilities for practical applications of Pd-P electrodes.

\section{Acknowledgements}

E. De Robertis is grateful to the CAPES (Project BEX 049800-9) and CNPq (Project 140977/1999-6) and A. M. Fundo wishes to express her gratitude to FCT (Scholarship SFRH/BD/2918/2000). 


\section{References}

1. Hu, C.-C.; Wen, T-C.; Electrochim. Acta 1998, 43, 1747.

2. Tanaka, S.; Hirose, N.; Tamaki, T.; Ogata, Y. H.; .J. Electrochem. Soc. 2000, 147, 2242.

3. Królikowski, A.; Wiecko, A.; Electrochim. Acta 2002, 47, 2065.

4. Li, A.; Liang, W.; Hughes, R.; Catal. Today 2000, 56, 45.

5. Langmaier, J.; Samec, Z.; J. Electroanal. Chem. 1996, 402, 107.

6. Iwakura, C.; Yoshida, Y.; Inoue, H.; J. Electroanal. Chem. 1997, 431, 43.

7. Andonoglou, Ph. P.; Jannakoudakis, A. D.; Electrochim. Acta 1997, 42, 1905.

8. Pyun, S.-I.; Yang, T.-H.; Kim, C.-S.; Appl. Electrochem. 1996, 26, 953.

9. Yang, Y.-F.; Zhou, Y.-H.; Cha, C.-S.; Electrochim. Acta 1995, 40, 2579.

10. Shu, J.; Grandjean, B. P. A.; Ghali, E.; Kaliaguine, S.; J. Electrochem. Soc. 1993, 140, 3175.

11. Chou, M. L.; Manning, N.; Chen, H.; Thin Solid Films 1992, 213, 64.

12. Steinmetz, P.; Alperine, S.; Friant-Constantini, A.; Josso, P.; Surf. Coat. Tech. 1990, 43/44, 500.

13. Ocken, H.; Pound, B. G.; Lister, D. H.; Thin Solid Films 1989, 171, 313.

14. Yeung, K. L.; Christiansen, S. C.; Varma, A.; J. Membr. Sci. 1999, 159, 107.

15. Li, A.; Liang, W.; Hughes, R.; J. Membr. Sci. 1998, 149, 259.

16. Karmalkar, S.; Banerjee, J.; J. Electrochem. Soc. 1999, 146, 580.

17. Stremsdoerfer, G.; Calais, C.; Martin, J.; Clechet, J. P.; J. Electrochem. Soc. 1990, 137, 835.
18. Paseka, I.; Electrochim. Acta 1999, 44, 4551.

19. Paseka, I.; Electrochim. Acta 1995, 40, 1633.

20. Burchardt, T.; Hansen, V.; Valand, T.; Electrochim. Acta 2001, 46, 2761.

21. Buchardt, T.; Int. J. Hydrogen Energy 2000, 25, 627.

22. Podestá, J. J.; Piatti, R. C. V.; Arvia, A. J.; Int. J. Hydrogen Technol. 1997, 22, 753.

23. Shervedani, R. K.; Lasia, A.; J. Electrochem. Soc. 1997, 144, 511.

24. Mahdavi, B.; Miousse, D.; Fournier, J.; Ménard H.; Lessard, J.; Can. J. Chem. 1996, 74, 380.

25. Cheong, A. K.; Lasia, A.; Lessard, J.; J. Electrochem. Soc. 1993, 140, 2721.

26. ASTM B322-108, Standard Practice for Cleaning Metals Prior to Electroplating.

27. James, R. W.; The Optical Principles of the Diffraction of $X$-rays, Lawrence Bragg- Cornell University Press: New York, 1967.

28. Bonzinni B.; Cavallotti, P.L.; Scripta Materialia 1997, 36, 1245.

29. Homma, T.; Yamazaki, T.; Osaka, T.; J. Electrochem. Soc. 1992, 139, 732

30. Fundo, A. M.; MSc. Dissertation, Faculdade de Ciências da Universidade de Lisboa, Portugal, 2001.

31. Green, T.; Brito, D.; J. Electroanal. Chem. 1996, 412, 59

32. Yang, T.-H.; Pyun, S.-I.; J. Electroanal. Chem. 1996, 414, 127.

Received: November 3, 2003

Published on the web: January 31, 2005

FAPESP helped in meeting the publication costs of this article. 